\title{
The inclusion of the other in ourselves: reception and comprehension of refugees in Portugal
}

\section{Ana Vieira, José Carlos Marques, Miguel Prata Gomes \& Ricardo Vieira}

To cite this article: Ana Vieira, José Carlos Marques, Miguel Prata Gomes \& Ricardo Vieira (2017) The inclusion of the other in ourselves: reception and comprehension of refugees in Portugal, Intercultural Education, 28:2, 196-205, DOI: 10.1080/14675986.2017.1308658

To link to this article: http://dx.doi.org/10.1080/14675986.2017.1308658

\section{Published online: 10 Apr 2017.}

Submit your article to this journal

LII Article views: 84

Q View related articles $\longleftarrow$

View Crossmark data 


\title{
The inclusion of the other in ourselves: reception and comprehension of refugees in Portugal
}

\author{
Ana Vieira ${ }^{a}$ iD, José Carlos Marques ${ }^{a}$ (D), Miguel Prata Gomes ${ }^{b, c, d, e}$ (D) and \\ Ricardo Vieira ${ }^{a}$ \\ anterdisciplinary Center of Social Research, Polytechnic Institute of Leiria, Leiria, Portugal; ${ }^{b}$ Observatory \\ for SocioEducational Intervention and Applied Human Rights, Paula Frassinetti School of Education, \\ Porto, Portugal; Institute of Philosophy, University of Porto, Porto, Portugal; ${ }^{\mathrm{d} A n n e}$ Frank House, \\ Amsterdam, Holland; 'International Association for Intercultural Projects and Research, Porto, Portugal
}

\begin{abstract}
The intensification of different types of migration movements during the last decades is an expression of growing interconnections at the global level. The so called 'refugee crisis' is the most visible sign of this intensification. It currently challenges societies to rethink the processes of integrating those fleeing from humanitarian crises and wars. Portuguese civil society has pioneered the creation of a Refugee Support Platform, aimed to address the challenges associated with the arrival of refugee families. Within this platform, an e-learning course was created to help institutions and host families prepare for this task. In the article we first describe this course, focusing our analysis on the relevance of this initiative for institutions, families, and private citizens that wish to welcome refugees in Portugal. We then briefly reflect on the literature pertaining to intercultural dialogue and social tensions. In the final section we analyse the voices of those who attended the course. We conclude with an analysis of the contents of the course modules and the participation of the trainees as a contribution to their self-transformation.
\end{abstract}

\section{ARTICLE HISTORY}

Received 27 December 2016

Accepted 10 February 2017

\section{KEYWORDS}

Refugees; integration; intercultural mediation; Portugal

\section{Refugees in Portugal: context data}

The year 2015 was marked by an exponential increase in the number of asylum seekers throughout the European Union. ${ }^{1}$ Compared to the previous year, there was a $123 \%$ increase (from 562.680 in 2014, to 1.255 .640 in 2015). ${ }^{2}$ The majority of asylum seekers came from Middle Eastern and North African regions affected by sociopolitical upheaval, wars as well as the strengthening of several religious-fundamentalist groups. Portugal has not escaped such developments, registering a $97 \%$ increase in the number of asylum seekers between the aforementioned years (from 442 to 872 asylum seekers). ${ }^{3}$ Contrary to the rest of the EU, asylum seekers 
in Portugal do not hail primarily from the Middle East and North Africa. They have come to Portugal from countries like the Ukraine (42\% of total asylum seekers in 2015), Mali (9,8\%) and China (8,6\%). Despite the increase in the number of asylum seekers in the past few years, ${ }^{4}$ the granting of refugee status is fairly uncommon (20 in 2014, and 33 in 2015). ${ }^{5}$ The available data from Portugal indicate that these individuals are a small group when compared with the numbers of asylum seekers and refugees welcomed in other EU countries.

The migrants who have arrived in Portugal are also a group with very diverse characteristics in terms of countries of 'origin, religious affiliation, social class, professions, age and gender' (Santinho 2013, 6). Due to relatively low numbers, together with the heterogeneity of those arriving, the refugee issue has not been very pronounced in Portuguese discourses. In general, there has been an'absence of an extensive academic and political debate on the realities and daily hardships of this group' (Santinho 2013, 6). In addition, only a small group of institutions, mainly within the sphere of the State (for example, through the Portuguese Refugee Council, Social Security and Immigration and Borders Service) have been involved in the integration process.

The involvement of civil society organisations, families, and individuals in the process of integrating refugees had not been, until 2015, a focus for Portuguese society. The initiatives taken by Portuguese actors, with the aim of assisting and taking in refugees, therefore constitute something new in the country.

\section{Refugee Support Platform: a response from Portugal to the humanitarian crisis}

The European official/governmental responses to the emergence of the humanitarian crisis that became visible in Europe in 2015 have shown to be, and continue to be, greatly lacking when it comes to dealing with a situation that is only truly comparable to the flow of refugees that occurred immediately before and during the Second World War.

The Refugee Support Platform (PAR -Plataforma de Apoio aos Refugiados) was created in Portugal in the context of a very complex and volatile situation. The PAR (http://www.refugiados.pt/) represented a response by Portuguese civil society to provide assistance to refugees during the emerging humanitarian crisis. Among the 30 founding organisations (presently several hundred other organisations are members), we find the Portuguese Refugee Council, Portuguese Cáritas, Islamic Community of Lisbon, Jesuit Refugee Service, Dorotheans of the Portuguese Province, Oikos, Calouste Gulbenkian Foundation, as well as several higher education institutions, NGOs, companies, foundations, etc. PAR's mission is to'promote a culture of welcoming support for the refugees, both in Portuguese society and in the countries of origin and transit. ${ }^{\prime}$ In this sense, the partners advocate for solidarity and an effective European response, as a counterweight to prevailing nationalistic responses that attempt to demonise and push out refugees. A key 
aim has also been to combat increasing xenophobia and develop mechanisms of intercultural mediation. Therefore, PAR defines itself as a group of 'civil society institutions with the will, availability, and experience to receive refugees who, through a collaborative and articulated model, can make a meaningful contribution to address this challenge, as something complementary to what is expected from the State."

PAR is aware of both the urgency associated with humanitarian action, demanding steps to facilitate the immediate reception of refugees, as well as the need for interventions with a medium/long-term character to tackle more political, economic, educational and social challenges.

The two axes of PAR's action are:

- Project PAR Families: creation of a project focusing on the reception and integration of refugee children and their families in Portugal, in a communitarian context, with the involvement of local institutions (Municipalities, IPSS, Associations, Religious Institutions, Schools, etc.) that strive to involve regular Portuguese families. We highlight here the option of a communitarian reception (in families and/or private homes), aligned with the official policy of the Portuguese State, in contrast to institutional reception (in dedicated institutions), practised by various other European states. Within this project, PAR has developed a training course (see below) in order to help members of local institutions develop the competencies needed to adequately welcome refugees. The course has a strong focus on (intercultural) dialogue and (intercultural) mediation.

- Project PAR Front Line: providing support to refugees in the countries of origin or in neighbouring countries, through the work of Cáritas and the Jesuit Refugee Service-Portugal (JSR). Funds are raised to support local work with the population at risk (internally displaced persons) and refugees, allowing them to live with more dignity and security. The volunteer programme in Lesbos and Athens (Greece), developed in loco by PAR, aims to reinforce the initial reception provided for the refugees through direct aid in the form of goods and financial support (see www.refugiados.pt/sobre/).

\section{Intercultural dialogue, reception of refugees and mediation}

- Dialogue can be viewed as an interaction that fosters debate and discussion, listening and talking, sometimes even disagreement and conflict. If dialogue is a source and opportunity for enrichment through an exchange that can generate 'third cultures' (Brockman 1998), 'third persons' and 'third instructed' (Serres 1993), 'cultural 'Métissages' (Vieira and Vieira 2016a,b), then the truth is that all this interaction can generate tension and friction. In fact, it is not easy for most of us to welcome and appreciate difference. For that reason, one of the topics we included in the module on 'Intercultural 
Dialogue' was that of intercultural mediation as a social pedagogy for hospitality (Baptista 2005), and for interculturality. For us, it is this mediation that counteracts monolithic integration processes and contributes to the development of an intercultural inclusion of the other.

- Intercultural mediation requires a considerable capacity for active listening, understanding, and respect for the other. That is why throughout the course we sought to amplify the potential of intercultural mediation as a vehicle for the construction of increased intercultural communication and more dialogical and intercultural interactions (Laplantine and Nouss 2002; Vieira 2014). To mediate implies active listening and striving to truly understand the other, all the others, in their own rationality. Therefore, it is not enough to tolerate, it is necessary to respect, even when disagreeing with somebody else's views. To socioculturally mediate is to find third places of understanding between sometimes extreme positions, that are not yet, necessarily, in a state of conflict but that have demonstrated a potential for social tension and open disagreement.

- Sociocultural mediation goes beyond 'tolerance' and seeks transformation of all those involved. It is imperative that the sociocultural mediator promotes multi-topic hermeneutics (Vieira 2011, 2013), leading to understanding and respect, although this does not necessarily mean agreement and identification. It is our opinion that if we tolerate intolerance, we accept injustice. Will a mediator tolerate and recommend being tolerant towards someone who harms another person? Or does the sociocultural mediator need to act and intervene, temporarily forfeiting the principles of classic mediation, based on neutrality and impartiality. In truth, passive tolerance leads to active intolerance or leaves the path open for it (Heritier 1999). It means that if one tolerates intolerant actions, without mediation and containment, one amplifies intolerance.

\section{Training Course: For a better reception - Reception and integration of refugees in Portugal}

The Training Course For a better reception - Reception and Integration of Refugees in Portugal, promoted by PAR with the clear objective of implementing socio-educational interventions, started in October 2015, with a total enrolment of approximately 800 persons associated with refugee reception programmes.

The course was a response to migration into Portugal that focuses on receiving refugees in a communitarian environment (not in specialised institutional environment). This decision was based on the philosophy that a communitarian response is more conducive to preventing future exclusion. In short, refugees in Portugal are received in family homes and/or private homes of organisations. This requires the participation and involvement of individuals and families, many who lack specific 
knowledge and experience with respect to such interventions. Due to this reality, the need to organise a training/preparation course for such actors was obvious. Those willing to receive refugees, by means of this course, have at their disposal an instrument that allows them access to basic information regarding key themes related to refugees and their reception.

The course, available online (with 2 in-class sessions), is totally free of charge and contains 10 learning modules: Reception; Ethics and Hospitality; Intercultural Dialogue; Interreligious Dialogue; Trauma and Mental Health in the Refugee Population; International Law; Asylum and Refugee Issues; Socio-Educational Intervention in the Context of Human Rights; Islam; Gender Issues; Racism and Xenophobia. Teachers from several Portuguese higher education institutions and/or specialists in a particular topic have been given the responsibility to teach a particular module. The various modules in the course can be seen as a path that goes from reception/hospitality (the humanity of receiving), through questions of mediation and intercultural dialogue to the deconstruction of prejudices and stereotypes. It introduces participants to practical topics such as 'helping' the other (taking into account the legal context of the population traumatized by conflict ...), and also suggests different ways of receiving and assisting refugees, taking into account the cultural diversity of the families arriving in the new country. The initial course lasted for two-and-a-half months (from late October 2015 to early January 2016), and each module took approximately one week to cover the content with the trainees.

The 'teachers' of the modules made available a number of support materials (texts, videos, links for consultation, etc.) that were then explored basically through a dialogue that took place in virtual meetings created for that purpose. Some modules were limited to a single virtual meeting, while others had several. The interactions between all the participants and the 'teachers' were sometimes heated and confrontational but such encounters did provide more depth. The final evaluation session showed that the majority of the participants were very satisfied and that they had gained a lot. Also, a series of three other courses/training sessions/ workshops have developed in the meantime, targeting professionals working in area social intervention in all Portuguese municipalities.

The authors of this paper participated in this course with a module entitled: 'Intercultural Dialogue'. We will, therefore, in the next section, reflect on the dynamics that have been developed during this module, and the possibilities for the inclusion of 'the other' in an intercultural way, and on intercultural mediation skills.

\section{Trainees' voices and the interaction with trainers}

In this section we use the trainee discourses to identify the personal changes that arose from their dialogic participation in the module 'Intercultural Dialogue'. The purpose of this section is to illustrate how the trainees constructed a third culture 
by blending their pre-existing knowledge with the experience and reflections that were developed during the course:

Intercultural mediation distances itself from pure conflict resolution, positioning itself in a preventive perspective, possessing several skills, being essentially transformative of social relations. This implies a social mediator/social intervenor that seeks to reshape social situations (...), with the involvement of the participant, aiming for the construction of hospitality as a human value. Adopting, therefore, an attitude of inclusion, reception. It is fundamental that intercultural communication positions itself in the comprehension of the other 'intercomprehension'), where the intercultural mediator has a fundamental role in the management and resolution of conflicts of understanding, of decision, option, etc. - he/she will be the'translator, the facilitator' who stimulates intercomprehension and interculturality so that there is an understanding and, as a consequence, a welcoming of the newcomer. ${ }^{9}$ (Trainee A)

When reflecting on intercultural dialogue and human rights, it is fundamental to consider the complexity of cultures all over the world, and the historical and culturally shaped conception of these same human rights. Universalisation, not in an absolute sense and not through the imposition of a hegemonic culture, but through dialogue, based on ethnicity and morality, is essential. Given that the ideals of a particular culture, strong as they may be, are as incomplete as the very culture they belong to, then there is an extension to its full extent of that conscience of 'incompleteness.' 'There aren't, anywhere in the world, States or governments that find minimally coherent arguments to deny human dignity, especially when it relates to the right to peace, life, liberty, besides social rights, basic for human dignity'. (Trainee A)

What trainee $A$ states above allows us to understand a new paradigm of mediation that is based on the comprehension of the other, on active listening, in order to construct negotiated coexistence platforms.

Trainee B's comments demonstrate that he had grasped the criticism of Cartesian dualism, as well as the logic of two cultures (Snow 1959) and came to understand the need to construct third places and third cultures of variable geometry:

There is a sense of relativity present in all dimensions of life. We will hardly ever be faced with a situation where there is only a duality of criteria or arguments. Intercultural mediation seeks a place of mutual understanding that is not fixed and that implies mutual flexibility between individuals and cultures. In this intercultural model, impartiality seems to be a myth to me. The will to take fair decisions that benefit all interested parties seems to me a fundamental virtue in this process of intercultural mediation. (Trainee B)

Trainee $C$ emphasises the importance of cultural background, including religion and the existence of a different set of social practices.

Cultural mediation skills require a previous understanding of the alterity of the other, that is, the capacity to understand others as persons that have cultures, religions, customs, and social practices different from ours. Of course, all these aspects have to be respected in their essence. On the other hand, the one who receives or promotes cultural mediation has to free him/herself from the judgements that he/she makes about others. As dangerous as judging others is to think that we never judge, that we are neutral, that we are not vulnerable to the tendency of discriminating someone according to 
nationality, culture, religion, gender or sexual orientation. The 'know yourself' is the only way to prepare to host and mediate culturally those who seek our support. (Trainee C)

Finally, trainee D devotes special attention to refugees from Syria, whose cultural, social, and religious backgrounds have to be understood since the fact that they are fleeing from war does not oblige them to live in Europe and distance themselves from their original cultures.

In welcoming the other, and in particular refugees from Syria, I think it's essential that we understand their religious, cultural, social, and 'civilizational' background. Before we contact these persons, we should have a notion of who they are collectively, as a people and a society. The fact that they have run away from war and death in their countries of origin does not force them to accept as an inevitability to live as indigents in the countries where they seek asylum and to not have access to communication technologies and other basic living conditions.

I think that an intercultural mediator, in this situation, needs to have the capacity to empathize with the refugee, knowing, however, that she/he will never be able to truly understand the extreme conditions that person has experienced. Consequently, she/ he will never be able to truly make any judgment on that particular person or his/her experience, nor his/her expectations. To create empathy it is essential to know how to listen but also to respect cultural, religious, etc. differences, but also to respect the person's privacy and his/her right to not wanting to expose to strangers the history of his/ her personal life, the horrors that he/she has gone through and his/her deepest anguish. Therefore, as important as, or perhaps more important than, respecting cultural differences is to respect the person as a unique and individual human being. (Trainee D)

The work in the virtual meetings enabled the production of new knowledge both for the trainee and the trainers. The virtual meetings contributed to the learning and the transformation of selves. They were not, therefore, a sum of monologues. After various contributions by the trainees, the trainers reflected on what they had stated, offering theoretical/conceptual insights, with the aim of producing a synthesis between theory and practice.

\section{Final reflections}

What the trainees wrote in their comments demonstrates that, in general terms, they were already well versed on some of the major issues and dilemmas with respect to the work they were supposed to do. The comments by their peers became paths to further learning by the trainees. In relation to the classical notion of 'not forgetting to remain neutral' one cannot forget the deontological framework that frames our professional activity [be it a doctor, a nurse, a social assistant, social educator, a teacher .... . Too often neutrality is equated to 'common sense', reproduced without any reflection. Surely, science has a key role to play in showing how appeals to 'common sense' can be misleading, ideological, blind to power differentials, as well as culturally and temporally bound.

Due to positivism, the concept of neutrality has gained an almost sacred status when it comes to mediation. Almost every book, article, and author focusing on 
conflict resolution regards neutrality as a key starting point. This has crept into the modus operandi of many intellectuals who even refuse to question the concept. However, it is our opinion that neutrality is never humanly possible, even in the legal domain.

With due respect to authors who dedicate themselves to conflict mediation in a technical manner, we argue that in social intervention it is inevitable that the mediator will side with the weaker party. It is impossible to ignore power differentials and power dynamics. Mediation in its essence is intervention and any intervention takes place in a field where there are power differentials. Social intervention is in its core about involving/developing/supporting the weaker (a clear intention that is far from neutral) in dialogue with the powers, the institutions. There is no neutrality in such social intervention. The facilitator of the mediation process needs to be on the side of the oppressed, on the side of those who need support.

Social policies are also corrective measures in the fight against inequality and discrimination. Mediation does not imply taking a middle position. Mediation needs to be intercultural in order to occupy every 'middle place', 'middle term' between the parties, as a way to intervene socially to attain social equality.

In sum, the intercultural mediator is not a robot. She/he is a human being who wants to make our contexts more human. Of course, it is much easier to state'the mediator is neutral ... that he/she doesn't take sides' .... Of course, it is simpler to think about wars and conflicts when we talk about mediation. But social intervention is more than that, and intercultural mediation feeds on other cultural paradigms. Finally, the reception of refugees requires intercultural mediation, not mediation/conflict resolution.

\section{Notes}

1. The exception is composed by Latvia, Romania, and Slovakia which have registered a decrease in the number of applicants (Eurostat 2016).

2. Source: Eurostat (2016).

3. Portuguese Refugee Council; data available at http://www.cpr.pt/. These data do not include the 132 refugees that Portugal received until 7 March 2016 in the context of the EU Relocation Scheme (the country has offered to receive 10.500 refugees in this scheme).

4. Between 2002 and 2013, Portugal received, on average, 164 asylum requests a year (data available at http://www.cpr.pt/).

5. Also, 160 people received subsidiary protection status in 2015 and 91 people in 2014. This is a status granted to citizens 'of a third country or to a stateless person that cannot be considered a refugee, but in relation to which there are significant reasons to believe that he can't go back to his country of origin or, in the case of the stateless person, to the country on which he resided' (Article 2 of the Law (Lei) n 27/2008).

6. Plataforma de Apoio aos Refugiados. Mission: http://www.refugiados.pt/sobre/\#missao

7. Plataforma de Apoio aos Refugiados. Mission: http://www.refugiados.pt/sobre/\#missao 
8. IPSS: Instituição Particular de Solidariedade Social (Private Institution of Social Solidarity). Non-profit private institutions focused on supporting children, families, elderly, promotion of health, education and solving housing problems.

9. All trainees' quotations have been translated to English from Portuguese. All quotations were taken from the virtual meetings held during the development of our module 'Intercultural Dialogue' at the For a better reception - Reception and integration of refugees in Portugal training course.

\section{Disclosure statement}

No potential conflict of interest was reported by the authors.

\section{Funding}

This work was supported by the Fundação para a Ciência e a Tecnologia [Project UID/ SOC/04647/2013].

\section{Notes on contributors}

Ana Vieira is an adjunct professor (in Social Education and Socio-Pedagogical Mediation) at Polythecnic Institute of Leiria and a researcher at CICS.NOVA, Interdisciplinary Centre of Social Sciences (unit Leiria). She is member, among others, of the network RESMI (Higher Education Network for Intercultural Mediation). Her research has been on social education and sociopedagogical mediation.(ana.vieira@ipleiria.pt)

José Carlos Marques is a professor (in Sociology) at Polythecnic Institute of Leiria and researcher at CICS.NOVA, Interdisciplinary Centre of Social Sciences (unit Leiria). He is member, among others, of the network RESMI (Higher Education Network for Intercultural Mediation). His research interest focuses on contemporary Portuguese emigration flows, migrants' integration and transnational practices, migration policies, and highly skilled migration.(jose.marques@ipleiria.pt)

Miguel Prata Gomes (PhD in Philosophy - University of Salamanca, Spain) is a coordinator professor at Paula Frassinetti School of Education (Porto, Portugal) with expertise in the fields of Education and Intercultural Mediation, Human Rights, Philosophy of Education and Technology. His present research interests focus on building "critical thinking" in Intercultural Education/ Mediation, Citizenship and Development, Support Refugees and Human Rights. He is involved and coordinating several international research and intervention projects and networks which connect formal and informal education with social dilemmas in actual societies. He has published several articles and studies related to those topics. He was a board member of Paulo Freire Institute in Portugal, is a board member of AKTO - Human Rights and Democracy, member of RESMI (Higher Education Network for Intercultural Mediation), Director of International Association Intercultural Projects and Research, research member of Institute of Philosophy - University of Porto, researcher of the Observatory of Socio-Educational Intervention for the Applied Human Rights (Portugal) and Anne Frank House Project Coordinator in Portugal. (mpratagomes@gmail.com)

Ricardo Vieira is a full professor (in Anthropology of Education) at Polythecnic Institute of Leiria and a researcher at CICS. NOVA, Interdisciplinary Centre of Social Sciences (unit Leiria). He is member, among others, of the network RESMI (Higher Education Network for Intercultural 
Mediation). His research interests focus on identities, intercultural education and intercultural mediation. (rvieira@ipleiria.pt)

\section{ORCID}

Ana Vieira (iD http://orcid.org/0000-0002-3976-6359

José Carlos Marques (D) http://orcid.org/0000-0002-4690-5943

Miguel Prata Gomes (iD http://orcid.org/0000-0001-8563-7470

Ricardo Vieira (D) http://orcid.org/0000-0003-1529-1296

\section{References}

Baptista, Isabel. 2005. Dar rosto ao Futuro. A Educação como Compromisso Ético [Give a face to the future. Education as ethical commitment]. Porto: Profedições.

Brockman, John, org. 1998. A Terceira Cultura [The Third Culture]. Lisboa: Temas e Debates.

Eurostat. 2016. News release, 44/2016. March 4. Accessed May 2, 2016. http://ec.europa.eu/ eurostat/documents/2995521/7203832/3-04032016-AP-EN.pdf/

Heritier, Françoise. 1999. "O eu e o outro e a tolerância." [I and the Other and Tolerance.] In Uma mesma Ética para Todos? [Same Ethics for All?], edited by Jean-Pierre Changeaux, 109-119. Lisboa: Piaget.

Laplantine, François, and Alex Nouss. 2002. A Mestiçagem [The Miscegenation]. Lisboa: Instituto Piaget.

Lei n 27/2008 de 30 de junho. Diário da República: 1 a série, n 124. 2008. Accessed May 2, 2016. https://dre.pt/application/dir/pdf1s/2008/06/12400/0400304018.pdf\#1

Santinho, Maria Cristina. 2013. "Afinal, que asilo é este que não nos protege?" [What Kind of Asylum is This That Doesn't Protect Us, After All?] Etnográfica 17 (1): 5-29.

Serres, Michel. 1993. O Terceiro Instruído [The Third Instructed]. Lisboa: Instituto Piaget.

Snow, Charles Percy. 1959. The Two Cultures. London: Cambridge University Press.

Vieira, Ricardo. 2011. Educação e Diversidade Cultural, Notas de Antropologia de Educação [Education and Cultural Diversity, Notes of Anthropology of Education]. Porto: Edições Afrontamento.

Vieira, Ana Maria. 2013. Educação Social, Mediação Sociocultural [Social Education, Sociocultural Mediation]. Porto: Profedições.

Vieira, Ricardo. 2014. “Life Stories, Cultural Métissage and Personal Identities." SAGE Open 4 (1): 1-13. doi:10.1177/2158244013517241.

Vieira, Ana Maria, and Ricardo Vieira. 2016a. Pedagogia Social, Mediação Intercultural e (Trans) formações [Social Pedagogy, Intercultural Mediation and (Trans) Formations]. Porto: Profedições.

Vieira, Ana Maria, and Ricardo Vieira. 2016b. “Mediações Socioculturais: Conceitos e Contextos [Socio-cultural Mediations: Concepts and Contexts]." In Pedagogias de Mediação Intercultural e Intervenção [Pedagogies of Intercultural Mediation and Intervention], edited by Ricardo Vieira, José Carlos Marques and Ana Maria Vieira, Pedro Silva, Cristovão Margarido, 31-60. Porto: Edições Afrontamento. 